\title{
The internal processing as an opportunity to increase competitiveness and to generate new jobs: the case of Kosovo
}

\author{
Halil Kukaj ${ }^{1}$ and Burim Prenaj ${ }^{2}$
}

1 University of Prizren "Ukshin Hoti". E-mail: halilkukaj@yahoo.com

2 Fama College- Prishtine. E-mail: prenajburim@gmail.com

\begin{abstract}
Global competition compels corporations to increase competitiveness by lowering production costs. Internationally affirmed brand corporations achieve to lower production costs by applying different forms of international business cooperation with business entities in developing countries. One of the forms of international business cooperation is "internal processing" by which cooperation the internationally affirmed brand corporations manage to reduce production costs, while businesses in developing countries realize the profits for themselves and contribute to reducing the level of unemployment in their countries. Given the positive aspects of internal processing, the paper aims to sensitize as much as possible the business entities to implement this form of business cooperation. Based on the analysis of data collected by the Customs Administration of Kosovo it can be concluded that in Kosovo, internal processing has been implemented very little, but we recommend that in the future to intensify the implementation of the internal processing in Kosovo.
\end{abstract}

Keywords: International business operations, customs procedures, customs procedures with economic effect

\section{INTRODUCTION}

Nowadays, businesses face global competition. In such circumstances, in order to increase competitiveness, they are forced to implement different forms of international business cooperation. One of the forms of international business cooperation is "internal processing". Internal processing is based on the contract for the integration of production factors of the local partner with the external partner. External partner usually brings "know-how", raw materials and reproductive materials necessary for the production of certain products, while local partner engages its production capacity (facilities, infrastructure, employees,) to manufacture finished products under the supervision and control of the external partner. The finished products bear the brand of the external partner, which is usually internationally renowned brand. Therefore, in this kind of cooperation, the foreign partner usually takes the obligation of placement of products in international markets (Kukaj, 2014). Business entities in the developed countries implement this form of cooperation aiming to reduce production costs, while entities in developing countries realize profits for themselves and contribute to the reduction of unemployment in their countries by such cooperation. As noted by (Andrianic, 2001), internal production, as a form of business 
cooperation, is attractive in cases where the local market is too small to be attractive for foreign direct investment. Given the positive aspects of inward processing, the majority of developing countries implement various measures to encourage corporations of developed countries to enter into cooperation with local business entities, final internal processing (Sinanagic, 2002). The purpose of this paper is to reflect the internal processing as an international business operation, in particular, the experiences of its implementation in Kosovo with emphasis that the internal processing has had impact on economic growth and has generated new jobs in Kosovo. Based on the analysis of data collected by the Customs Administration of Kosovo, it is concluded that the influence of internal processing in economic growth and the generation of new jobs has been very small. Given the positive aspects of the internal processing, we recommend Kosovo business entities to apply, as much as possible, this form of international cooperation. We also recommend to the institutions of Kosovo to apply various measures to encourage this form of international business cooperation.

\section{INTERNAL PROCESSING AS AN INTERNATIONAL BUSINESS COOPERATION FORM}

Internal processing is based on contract for the integration of factors of production of local partner with external partner. External partner usually brings "know-how", raw materials and necessary reproductive materials for the production of certain products, while local partner engages its production capacity (facilities, infrastructure, employees,) to produce finished products under the supervision and control of the external partner. The finished products bear the trademark of external partner, which, usually is internationally renowned brand. Therefore, in this kind of cooperation, the foreign partner usually takes the obligation of placement of products in international markets (Kukaj, 2014).

This form of cooperation brings products of high quality and low cost and also this form of cooperation provides them with competitive advantages in the market. High quality and low cost production result from the combination of the advantages of external production partners and those of the local ones.

Local partner benefits from such cooperation are:

- provision of contemporary "know-how";

- better use of production capacity,

- avoidance of the problems associated with the placement of products and

- gaining knowledge from renowned foreign partner.

The disadvantages of this form of cooperation for local partners are:

-local partner remains anonymous because his name does not appear on products;

- after the end of the contract, there is a risk that the production capacity remains unused. This risk is higher when production capacities are high and are used for the production of specific items. 
External partner benefits from this form of cooperation are:

- increases the amount of production without investing in developing production capacity and thus avoids the risk of major investment;

- exploits cheap labor of local partner,

- uses free inputs in the country;

- facilitates the placement of products in the local market;

- eliminates the problem of currency risk;

- exceeds barriers of local customs.

The disadvantages of this form of cooperation for external partner are:

- difficulties in finding appropriate local partner,

- possibilities of creating future competitor, etc. (Andrianic, 2001).

Concerning this way of cooperation, external partner's mainly engagement has to do with the placement. They transfer production in the foreign market, usually in the developing country which provides lower cost of production.

Foreign companies, which implement internal processing, are mostly known brand enterprises of labor-demanding intensive activities, eg textile industry, confectionary industry, leather and shoes processing industry etc.

This form of cooperation is attractive when the local market is too small to engage foreign direct investment.

\section{IMPORTS OF GOODS FOR INTERNAL PROCESSING}

Raw material and reproductive material of the external partner is imported by the local partner in order to be processed by implementing the customs procedure of internal processing. Customs procedure of internal processing permits the import of foreign goods to be processed in the country free from import charges and the products resulting from the processing (products obtained) must be re-exported within a given period or settled in another customs procedure or placed in a customs-approved use.

Imports of goods for internal processing can be executed only with the permission (authorization) for internal processing issued by the central Customs to the entity that has applied in written form. According to the proposal of the applicant, the central Customs unit shall designate the term of license. The license duration expresses the term within which the products obtained must be re-exported and, if products obtained are not reexported, then, the permission must be required for any other customs procedure or customs approved use. The license duration is set depending on the time required for processing of products. This deadline may be extended on the basis of a reasonable request which is presented on time to the central Customs unit, but the general term can not be longer than 12 months from the date that goods get placed on the internal processing procedure.

For the discharge of the internal processing procedure, the central customs unit in ac- 
cordance with the applicant determines the rate of use. The rate of use represents the amount of products obtained from the quantity of goods imported for free, it means, setting the expenditure norms for the unit. For example if the case of internal processing is textile and other materials for the production of men's suits, then the imported material for internal processing flows with re-exporting of sewed costumes, designs and sizes according to the norms set (eg. $3 \mathrm{~m}$ of coating = 1 pair of men's suits).

Internal processing may include different processing operations, starting from assembling, gluing, sewing, painting, repairing up to more complex processing.

Based on a written request of the applicant for internal processing, the central customs unit may allow the equivalence applying. Equivalence allows the license holder to use the identical goods released for free circulation for internal processing.

Central customs unit may allow the license holder for internal processing to utilize the equivalence. Exporting equivalence entitles the license holder to export the acquired products (identical goods released for free circulation) prior to import goods for internal processing. It means that export is allowed before import.

Import of goods for internal processing becomes duty free import in two ways: with suspension and with drawback.

Imports of goods for internal processing with suspension - is based on that the holder of the license for internal processing is duty free for imports, it means that import duties are suspended, but after the expiration of the license, the products obtained must be reexported, or placed in another customs procedure or placed in a customs-approved use. If the products obtained (and intact goods) are not moved within the deadline of internal processing procedure with suspension, then the importer is obliged to pay import duties on imported goods plus the compensatory interest.

In order to import goods for internal processing with suspension it is necessary that the license holder submits a bank guarantee to the customs unit.

License holder places the goods on the internal processing procedure with suspension, presenting to the Customs Offices the following:

- license,

- UCD, marked with IM-5 in the first box, while in 37 one it is written the code of customs procedure, where the first two digits will be 51 (suspension), while two other figures show the previous procedure, eg. if the goods are imported directly from abroad, the figure will be 00 ,in that case the CPC would be 5100 , or if they come from the customs warehouse (71), the CPC would be 5171, if they come from another internal processing process with suspension (51), then CPC would be the 5151 .

- An attached document with the following information:

- Name and address of the applicant (the pleader and the operator);

- The nature of the processing of goods;

- A description of importing goods and products obtained;

- The estimated rate of operation;

- The period for the procedure discharge;

- The country of processing. 
The license holder can discharge the procedure of internal processing with suspension if within the allowed term allowed, the products obtained and untouched imported goods by the procedure of internal processing with suspension are removed and placed in another customs procedure or approved customs execution, as follows:

- re-exporting;

- transferring to another customs procedure, eg customs storage, processing under customs control, temporary import;

- transferring to another license holder for internal processing with suspension;

- releasing for free circulation, paying import duties plus compensatory interest;

- transferring to any other customs permitted operation, such as duty-free shops (duty free shops) at international airports, UNMIK, KFOR, embassies, charities etc. (In such cases they must have a certificate from the abovementioned organizations);

- liquidating under customs supervision.

Discharge of the internal processing procedure with suspension through re-export is done by submitting UCD to the appropriate customs unit, which is noted with EX-3 code in the first box whereas in the 37 box is indicated the customs procedure code 3151 .

The license holder is obliged to complete a report every quarter of the year where are presented all goods received and removed from the internal processing with suspension (discharge) and to submit it to the competent customs unit.

Imports of goods for internal processing with drawback -is based on that the license holder for internal processing for import pays import duties while paid import duties will be returned only if within the allowed term the products obtained and imported and untouched goods are taken away by the internal processing procedure.

License holder places the goods on the inward processing procedure with drawback while presenting to the Customs Offices unit the following:

- Authorization;

- UCD, where the code IM-4 is marked in the first box, the code of customs procedure is marked in the box 37 , the first two digits are 41 , while two second digits will be the subject of whether those goods are directly imported 00 (CPC would be 4100). If the goods come after a different procedure, for example, from customs filing 71 (CPC would be 4171) or by another procedure or the inward processing with suspension (it would be 4151);

- An attached document with the following information:

- Name and address of the applicant (the pleader and the operator);

- The nature of the processing of goods;

- A description of the imported goods and the products obtained;

- The estimated rate of operation;

- The period for the procedure discharge;

- The place of processing;

- A declaration of customs value (CV-1), when the value of imported goods is higher than $€ 5,000$. 
To use the internal processing with drawback, the license holder does not need to submit a bank guarantee.

The license holder can discharge the procedure of internal processing with drawback if within the allowed term, the products obtained and untouched imported goods by the procedure of internal processing are removed and placed in another customs procedure or approved customs execution as follows:

- re-exporting;

- transferring to another customs procedure, eg customs storage, processing under customs control, temporary import;

- transferring to other license holders of internal processing;

- releasing for free circulation;

- transferring into any other customs permitted operation, eg in duty-free shops (duty free shops) at international airports, to UNMIK, to KFOR, the humanitarian organizations etc.

Discharge of the internal processing procedure with drawback through re-export is done by submitting the appropriate customs unit UCD, EX-3 code is marked in the first box while the 37 box marks the code 3141 of customs procedure. The license holder has to complete a report every three months where are specified goods received and removed from the procedure of internal processing with drawback and submit it to the competent customs unit to demand repayment of the amounts paid (claims for refunding ).

Demand for refunding shall be fulfilled no longer than the deadline of one year from the date of payment of the duty (Customs Administration of Kosovo, 2005).

\section{THE IMPLEMENTATION OF THE INTERNAL PROCESSING IN KOSOVO}

The implementation of internal processing in Kosovo is seen from the following data.

Figure 1: The total value of imported goods

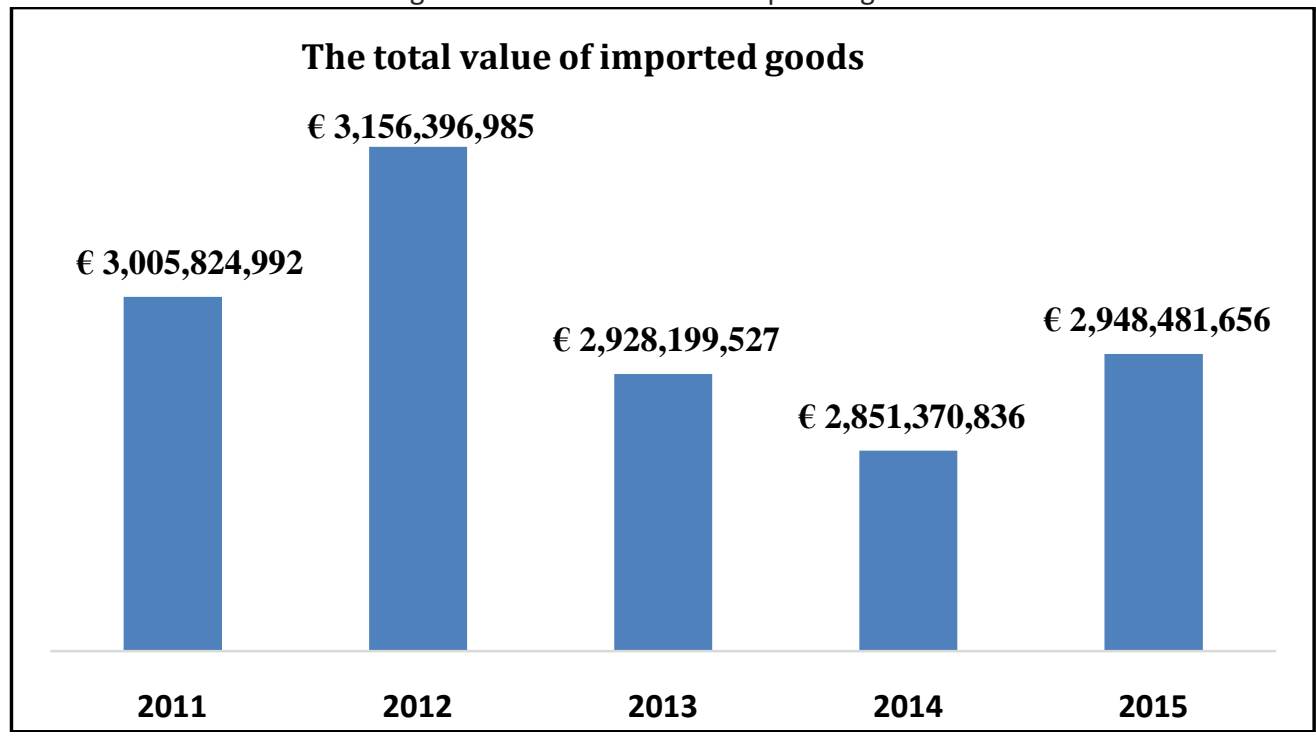

Source: Customs Administration of Kosovo 
The data in figure 1 show that the total value of imported goods in the reporting period has been relatively high and it ranges from 3.15 billion $€$ in 2012 to around $€ 2.85$ billion in 2014.

Table 1: Value of imported goods under customs procedures with economic impact

\begin{tabular}{|r|r|r|r|r|r|}
\hline \multirow{2}{*}{ Year } & \multicolumn{3}{|l|}{ Imports under customs procedures with economic impact } & \multicolumn{1}{c|}{ Total } \\
\cline { 2 - 6 } & 4100 & 5100 & 7100 & 9100 & \\
\hline 2011 & $7,747,498$ & $13,561,016$ & $516,837,960$ & $9,959,426$ & $548,105,900$ \\
\hline 2012 & $7,751,382$ & $14,054,257$ & $521,589,202$ & $10,682,923$ & $554,077,764$ \\
\hline 2013 & $10,334,143$ & $19,450,429$ & $350,875,627$ & $6,375,725$ & $387,035,924$ \\
\hline 2014 & $8,190,430$ & $33,467,743$ & $257,047,280$ & $10,500,742$ & $309,206,195$ \\
\hline 2015 & $4,647,891$ & $38,905,400$ & $246,430,607$ & $7,422,129$ & $297,406,027$ \\
\hline
\end{tabular}

Source: Customs Administration of Kosovo

The data in table 1 shows that during the reporting period, imports under customs procedure 7100 (filing customs) have the highest participation, while in the second place is the customs procedure 5100 (internal processing with suspension), the third place belongs to the customs procedure 9100 (temporary import), while the last place is for customs procedures 4100 (internal processing with drawback).

Table 2: The value of goods imported for internal processing

\begin{tabular}{|c|c|c|c|c|c|}
\hline \multirow[b]{3}{*}{ Year } & \multicolumn{4}{|c|}{ Imported goods for Internal Processing } & \multirow[b]{3}{*}{ Total } \\
\hline & \multicolumn{2}{|c|}{ IM5 } & \multicolumn{2}{|c|}{ IM4 } & \\
\hline & 5100 & 5171 & 4100 & 4171 & \\
\hline 2011 & $13,561,016$ & $47,313,448$ & $7,747,498$ & $1,172,316$ & $69,794,278$ \\
\hline 2012 & $14,054,257$ & $48,421,830$ & $7,751,382$ & $3,654,083$ & $73,881,552$ \\
\hline 2013 & $19,450,429$ & $35,851,478$ & $10,334,143$ & $1,126,696$ & $66,762,746$ \\
\hline 2014 & $33,476,743$ & $8,835,245$ & $8,190,430$ & $4,916,573$ & $55,418,991$ \\
\hline 2015 & $38,905,400$ & $1,168,115$ & $4,647,891$ & 973,341 & $45,694,747$ \\
\hline
\end{tabular}

Source: Customs Administration of Kosovo

The data in table 2 indicates that in the customs procedure IM5 (internal processing with suspension), the goods come mainly from customs warehouse (5171), and the direct goods come from abroad, there was oscillation within the reporting period. Also, it is seen that the customs procedure IM4 (internal processing with drawback), mainly, goods come directly from abroad (4100), and the arrival of goods from customs warehouse (4171) is smaller and it is with oscillation through the years. 
Figure 2: The share of imports for internal processing in total imports

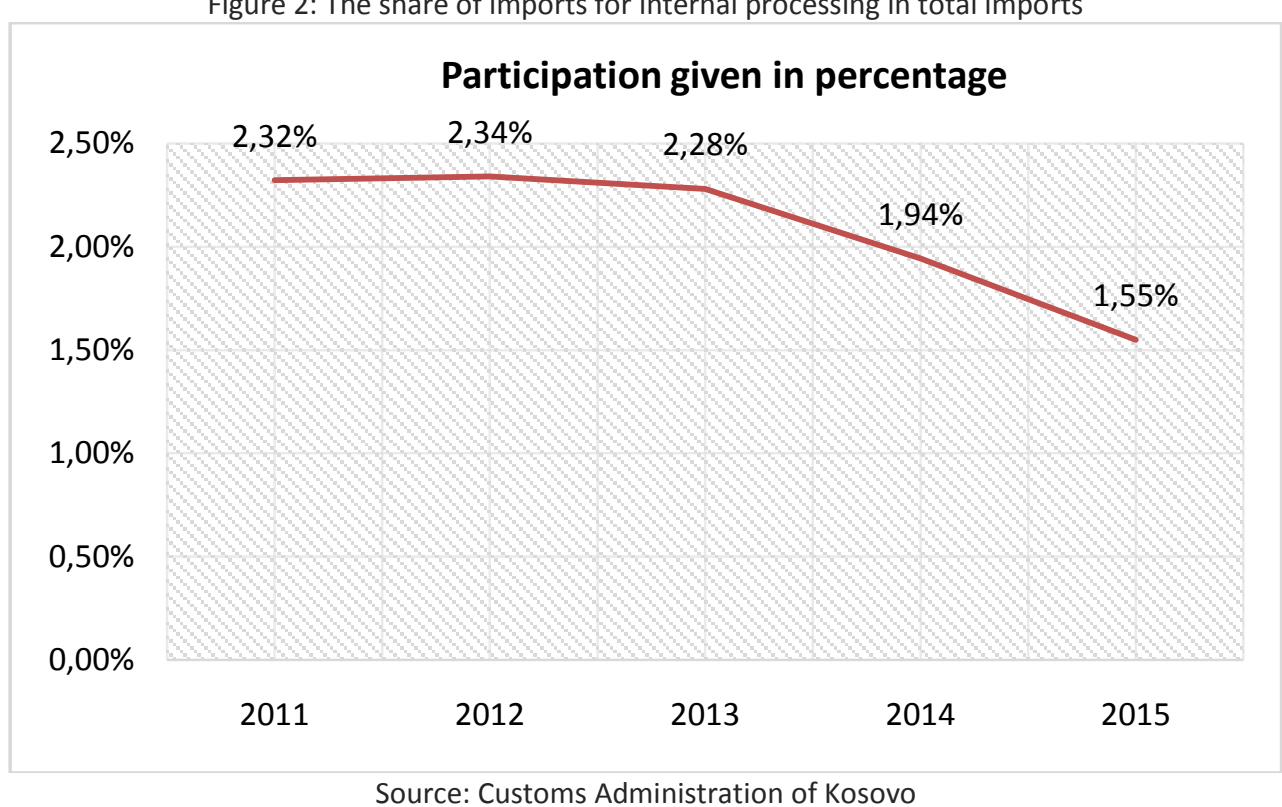

Source: Customs Administration of Kosovo

The data given in figure 2,indicates that the share of imports of goods for internal processing in total imports is very low and ranges from 2:32\% in 2011 up to 1:55\% in 2015. It is also considered that this participation has declined steadily during the reporting period.

Figure 3: The number of license users for inward processing

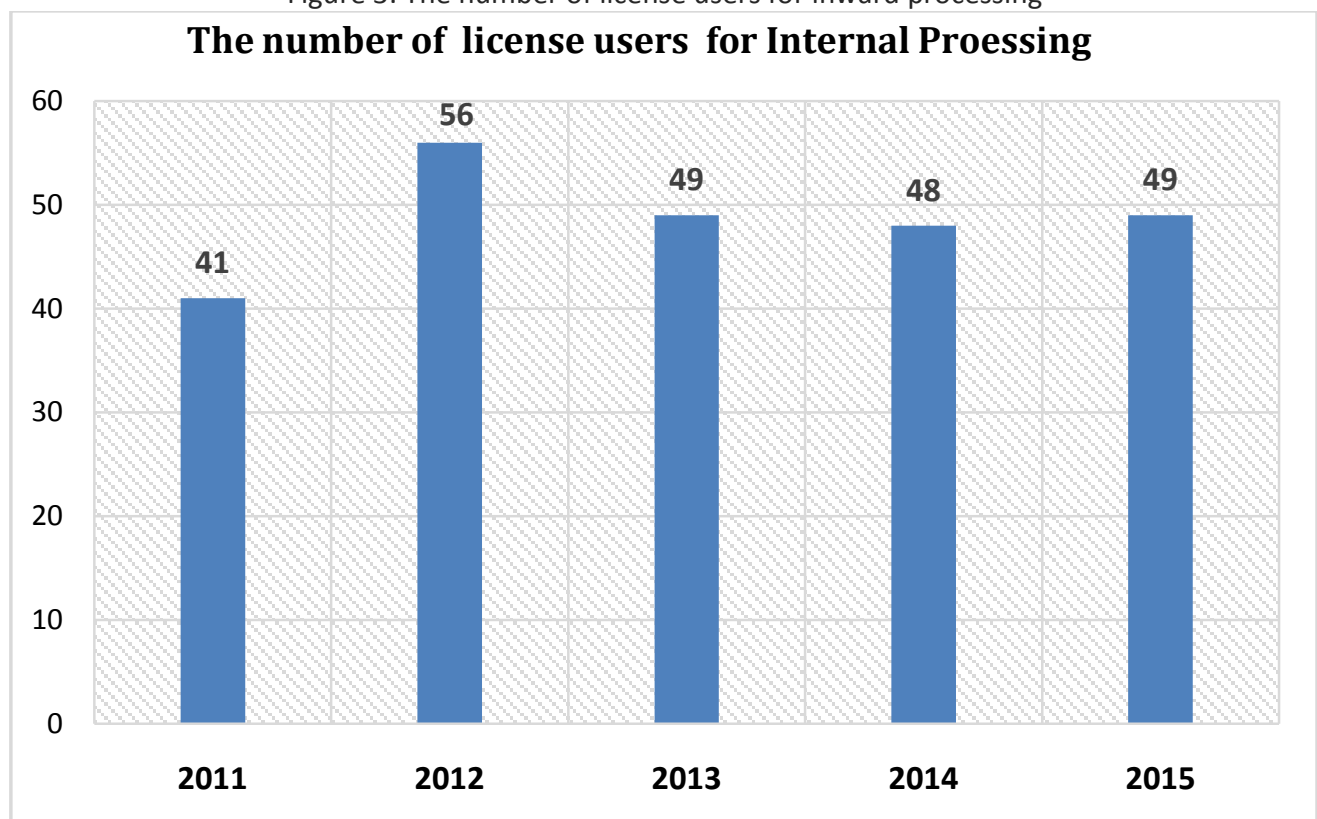

Source: Customs Administration of Kosovo

The data in figure 3 shows that the number of license users for internal processing is very small and after 2012 there was a decline. 


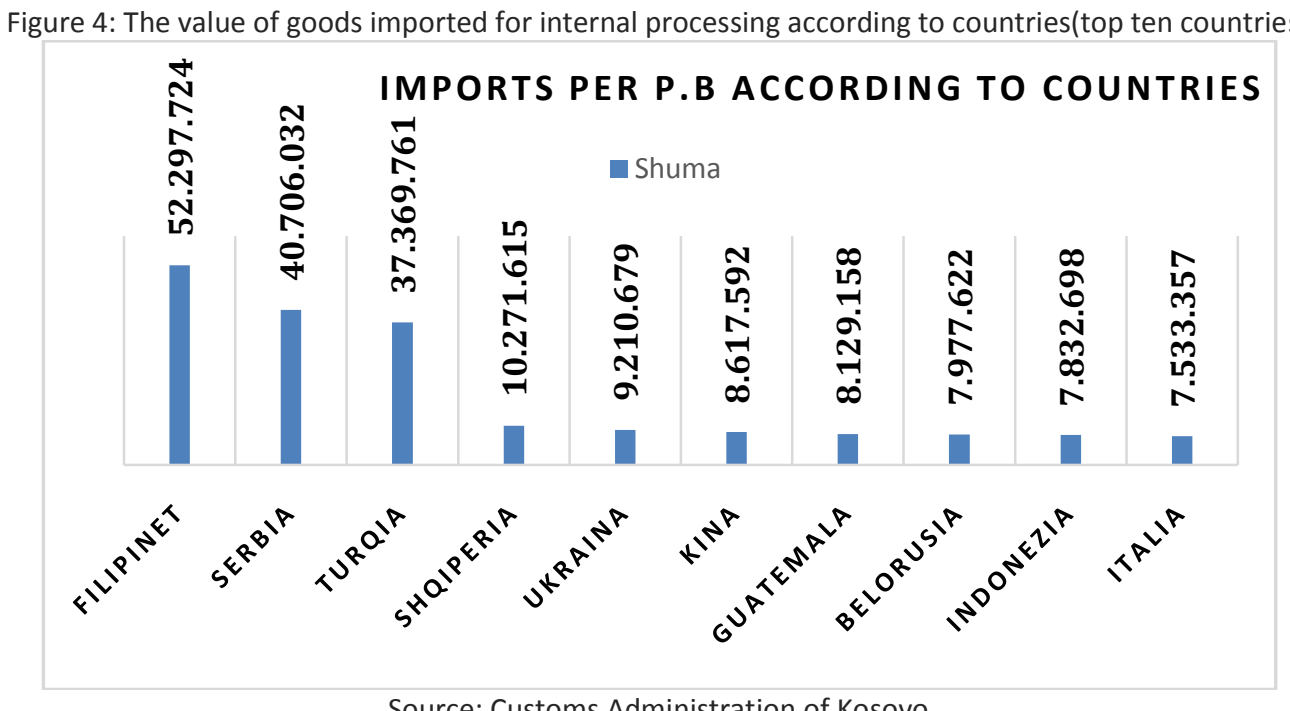

Source: Customs Administration of Kosovo

The data in figure 4, shows what are the top ten countries in terms of total imported goods for internal processing in Kosovo, within the reporting period. The first place is occupied by the Philippines followed by Serbia, and in tenth place is Italy.

Figure 5: Discharge of internal processing procedure

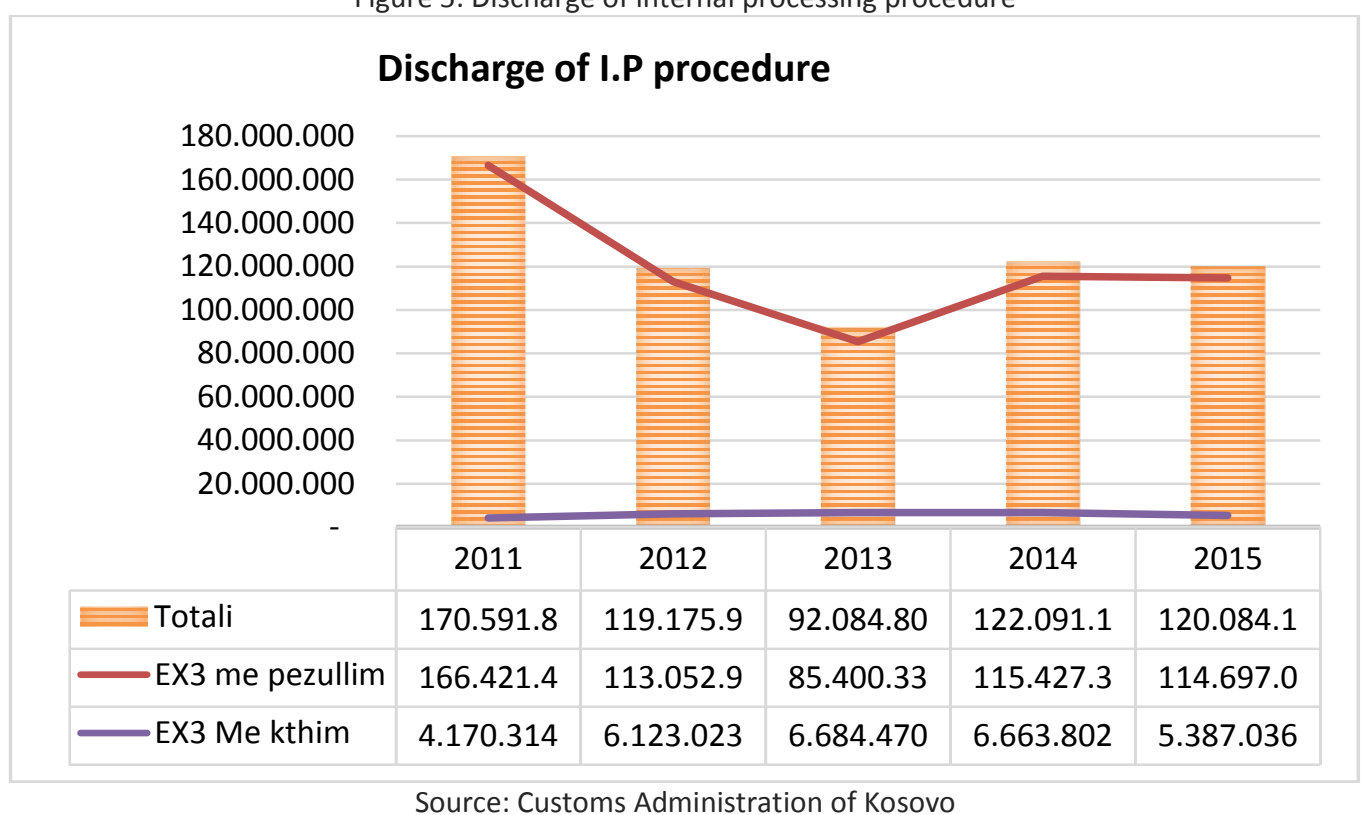

The data in figure 5, indicates that the majority of imports of internal processing is discharged through the export of the products obtained (EX3 with suspension), while the export of the products obtained with the drawback (EX3 with drawback) is very small . 


\section{CONCLUSION}

From what is stated above it can be concluded that the internal processing is an advantageous business operation for corporations in developed countries and for business entities in developing countries, too. Corporations of developed countries through this form of international business cooperation manage to reduce production costs and increase competitiveness in terms of global competition which is increasing fiercely. Implementation of internal processing of business entities in Kosovo is very low. Such findings are supported by the data that the share of goods imported for internal processing in total imports is very low and ranges from 2:32\% in 2011 up to $1: 55 \%$ in 2015 . Also the number of users of internal processing license is very small and ranges from 41 to 56 users. The contribution of internal processing in generating economic activity and reducing unemployment in Kosovo is small. Among the causes of such a situation may be the restriction of the free movement of the citizens of Kosovo to developed countries with the consequences of limitation of the possibility to find potential partners for business. Also, businessmen from Kosova remain not informed for opportunities offered by Customs Administration of Kosovo to import goods under the customs procedure of internal processing.

Given the positive aspects of internal processing, we recommend that the government institutions of Kosovo take measures to stimulate internal processing through fiscal policy measures, organize meetings of foreign businessmen with local ones, inform them directly about the possibilities that government provides to the dynamism of internal processing etc.

\section{LITERATURE}

Hill, Ch., (2007). International Business: Competing in the Global Marketplace. NY: Cengage Learning. NY: McGraw-Hill/Irwin

Kukaj, H., (2014), Biznesi Ndërkombëtar, Kolegji FAMA, Prishtinë.

Moosa (2002). Foreign direct investment. Theory, evidence and practice. Hampshire - UK: Palgrave Publisher, Ltd. (formerly Macmillan Press, Ltd).

Kristo. I., (2004). Biznesi Ndërkombëtar, PEGI, Tiranë.

Sinanagic, M., (2002), Medunarodni Marketing, Ekonomski Fakultet, Sarajevo.

Vugrinec Hitrec, V., Razvijanje nacionalne konkurentske sposobnosti, Ekonomija, 1/1996, Zagreb.

Andrianic, I., (2001), Vanjska Trgovina-Kako poslovati s inozemstvom, Mikrorad, Zagreb. Uldedaj, Gj., Verçuni, A., (2003) Marketingu Ndërkombëtar, Libri Universitar, Tiranë. .Customs Administration of Kosovo (2005). Customs Code of Kosovo. Prishtine: Customs Administration of Kosovo. 